\author{
JACEK HADRYŚ \\ Uniwersytet im. Adama Mickiewicza w Poznaniu \\ Wydział Teologiczny
}

\title{
Życie w rodzinie szansą pełnego udziału w życiu Bożym
}

Life in the Family as a Chance to Full Participation in the Life of God

Chrześcijańskie życie duchowe jest rzeczywistością dynamiczną i polega na uczestniczeniu w życiu Bożym. Udział w życiu Bożym jest dany człowiekowi, ale także zadany. Rozwój życia Bożego jest możliwy dzięki Chrystusowi, jednakże uzależniony od odpowiedzi człowieka na Bożą łaskę. Można zatem stwierdzić, iż źródłem życia duchowego jest Chrystus, początkiem przyjęcie sakramentu chrztu, a warunkiem rozwoju współpraca ochrzczonego z Chrystusem ${ }^{1}$. Na przyjmowanie tego daru i na dążenie do komunii z Bogiem wpływ ma wiele czynników, ale podstawowym wśród nich jest stan życia: inna jest specyfika dążenia do komunii z Bogiem kapłana, inna osoby zakonnej, inna osoby dorosłej żyjącej samotnie w świecie, a jeszcze inna kogoś, kto żyje w rodzinie. Celem badań, których wyniki są prezentowane w niniejszej dysertacji, było przeanalizowanie chrześcijańskiego życia rodzinnego pod kątem jego roli w dążeniu małżonków do pełnego udziału w życiu Bożym². Analizując dokumenty Kościoła, dotyczące chrześcijańskiego życia duchowego oraz rodzinnego i małżeńskiego, szczególnie adhortację apostolską świętego Jana Pawła II Familiaris consortio ${ }^{3}$,

${ }^{1}$ „, Łaska Chrystusa jest darem darmo danym [...]. Jest to taska uświęcajaca lub przebóstwiajaca, otrzymana na chrzcie. Jest ona w nas źródłem dzieła uświęcenia”. Katechizm Kościoła katolickiego, Poznań 1999, dalej: KKK.

${ }^{2}$ Badania na podobny temat, ale podjęte $\mathrm{w}$ innym kluczu, autor niniejszego przedłożenia zamieścił w: Małżeństwo droga do komunii z Bogiem w świetle „Familiaris consortio” Jana Pawła II, „Teologia i Moralność” 9 (2011), s. 25-39.

${ }^{3}$ Jan Paweł II, Familiaris consortio, Adhortacja apostolska do biskupów, kapłanów $i$ wiernych całego Kościoła katolickiego o zadaniach rodziny chrześcijańskiej w świecie współczesnym, Rzym 22.11.1981, w: Adhortacje apostolskie Ojca Świętego Jana Pawła II, Kraków 1996, dalej: FC. 
najpierw wskazano na istotne elementy pełnego udziału w życiu Bożym, następnie na podstawę i specyfikę uświęcenia małżonków w rodzinie, na motywacje osobistego uświęcenia i ich udział w potrójnej misji Chrystusa, by w końcu wskazać na środki, praktyki oraz postawy pomocne w dążeniu do pełni Bożego życia poprzez życie $\mathrm{w}$ rodzinie. Wyniki przeprowadzonych analiz zamieszczono $\mathrm{W}$ podsumowaniu.

\section{ISTOTNE ELEMENTY PEŁNEGO UDZIAŁU W ŻYCIU BOŻYM}

Na soborze watykańskim II stwierdzono, iż „,wszyscy chrześcijanie jakiegokolwiek stanu i zawodu powołani są do pełni życia chrześcijańskiego"4. Pełny udział w życiu Bożym jest określany m.in. jako naśladowanie Chrystusa, zjednoczenie z Bogiem, komunia z Bogiem, pełnienie woli Bożej, doskonałość chrześcijańska, świętośćs. Najbardziej znanym z tychże określeń jest świętość. Zgodnie z nauczaniem Soboru Watykańskiego II, wszyscy „,hrześcijanie zachęcani są i zobowiązani do osiaggania świętości i doskonałości własnego stanu"6. Świętość chrześcijanina polega na udziale w świętości Boga: im jest bliżej Boga, tym W większym stopniu uczestniczy w Jego świętości. Świętość jest darem i zadaniem: „Bądźcie świętymi, bo Ja jestem święty, Pan Bóg wasz!” (Kpł 19,2). Świętość zakłada przede wszystkim osobową relację z Bogiem, dokonującą się w Chrystusie i przez Chrystusa. W dążeniu do świętości istotna jest głęboka, osobista więź z Chrystusem, wyrażająca się w coraz doskonalszej postawie moralnej. Jeśli chrześcijanin autentycznie trwa w przyjaźni z Chrystusem, to jest niemożliwe, by świadomie i dobrowolnie chciał postępować wbrew Jego woli, przeciwnie, taki człowiek pragnie przez wszystko okazywać Chrystusowi miłość. Świętości nie można rozumieć jako bezgrzeszności, ale jako dążenie do niej ze względu na osobistą więź z Chrystusem. Realizacja powołania do świętości dokonuje się we wspólnocie Kościoła, w której Bóg daje człowiekowi wszystko, co jest potrzebne, aby mógł osiagnąć pełny udział w Bożym życiu. Trudno sobie wyobrazić chrześcijanina szczerze dążącego do głębokiej więzi z Chrystusem i jednocześnie odnoszącego się z lekceważeniem do Mistycznego Ciała Chrystusa, którym jest Kościół. Skoro każdy ochrzczony jest powołany przez Boga do świętości, to dotyczy to także chrześcijan, którzy zawarli sakramentalny związek małżeński. Święty Jan Paweł II stwierdził, iż ,wszyscy małżonkowie są powoła-

\footnotetext{
${ }^{4}$ Sobór Watykański II, Konstytucja dogmatyczna o Kościele Lumen gentium, w: Sobór Watykański II, Konstytucje, dekrety, deklaracje, Poznań 2002, 12, dalej KK.

${ }^{5}$ Por. J. Hadryś, Różne ujęcia petni życia chrześcijańskiego, w: Zawsze z Tobq. Księga pamiatkowa ofiarowana biskupowi Zdzisławowi Fortuniakowi na pięćdziesięciolecie kapłaństwa, Poznań 2013, s. 243-247. Zob. także J. Gogola, Teologia komunii z Bogiem, Kraków 2003, s. 101-108 .

${ }^{6} \mathrm{KK} 42$.
} 
ni do świętości w małżeństwie według woli Boga, a to powołanie realizuje się w miarę, jak osoba ludzka potrafi odpowiedzieć na przykazanie Boże, ożywiona spokojną ufnością w łaskę Bożą i we własną wolę ”."

W świetle powyższej wypowiedzi świętego Jana Pawła II można powiedzieć, iż istnieją trzy istotne elementy charakteryzujące pełnię chrześcijańskiego życia: głęboka, osobista więź chrześcijanina z Chrystusem, troska o poznanie i wypełnienie woli Bożej oraz szacunek i umiłowanie Kościoła. W każdym z wymienionych określeń pełni życia chrześcijańskiego te elementy występują, chociaż są różnie akcentowane. Więź z Chrystusem podkreślają określenia mówiące o zjednoczeniu czy komunii z Bogiem, natomiast wymiar moralny - określenia mówiące o doskonałości chrześcijańskiej czy pełnieniu woli Bożej. Wydaje się, iż mówiąc o świętości oraz o naśladowaniu Chrystusa, najlepiej dokonuje się połączenia wszystkich wspomnianych wymiarów, składających się na pełnię życia chrześcijańskiego, niemniej każde $\mathrm{z}$ tych ujęć zakłada głęboką, osobistą więź z Chrystusem oraz troskę o poznanie i wypełnienie woli Bożej, a w domyśle także umiłowanie Kościoła, czyli szacunek i odpowiedzialne zaangażowanie się w życie wspólnoty Kościoła. Miarą świętości jest miłość ${ }^{8}$, stąd - konkludując pierwszą część niniejszego przedłożenia - należy podkreślić, iż konsekwentne i radykalne życie według przykazania miłości Boga i bliźniego stanowi najistotniejszy element udziału w życiu Bożym i oznacza osiagnięcie jego pełni.

\section{PODSTAWA I SPECYFIKA UŚWIĘCENIA MAŁŻONKÓW}

Podstawowym środkiem uświęcenia chrześcijańskich małżonków jest sakrament małżeństwa. Święty Jan Paweł II powyższe twierdzenie ujął w następujący sposób: „właściwym źródłem i pierwotnym środkiem uświęcenia małżeństwa i rodziny chrześcijańskiej jest sakrament małżeństwa, który podejmuje i rozwija łaskę uświęcającą chrztu" ". Z papieskiego stwierdzenia wynika, iż przyjęcie sakramentów chrztu oraz małżeństwa można uznać za podstawę uświęcenia małżeństwa i rodziny. Sakrament chrztu wywołuje różne skutki, które zasadniczo można sprowadzić do pięciu: uwolnienie od grzechu pierworodnego i obdarowanie udziałem w życiu Bożym; przywrócenie godności dziecka Bożego i umożliwienie uczestnictwa w życiu Osób Trójcy Przenajświętszej; wszczepienie w Chrystusa i w Kościół oraz udział w potrójnym posłannictwie Chrystusa: kapłańskim, prorockim i królewskim. Pełnienie tegoż posłannictwa wyznacza całą życiową drogę chrześcijanina oraz jego dążenia do pełnego udziału w życiu Bo$\dot{z ̇ y m}^{10}$. Przyjmując sakrament chrztu, człowiek uzyskuje pełne prawo do korzy-

\footnotetext{
${ }^{7} \mathrm{FC} 34$

${ }^{8}$ Por. A. Marchetti, Zarys teologii życia duchowego, cz. I, Kraków 1996, s. 49-54.

${ }^{9}$ FC 56.

${ }^{10}$ Por. D. von Hildebrand, Transformation in Christ, San Francisco 2001, s. 5.
} 
stania z sakramentów i Słowa Bożego, jak również do wszelkich pozostałych pomocy duchowych ${ }^{11}$. Kiedy ochrzczony przyjmuje sakrament małżeństwa, to wówczas tenże sakrament, jak już wspomniano, rozwija w nim wszystkie łaski otrzymane podczas chrztu: „osobny sakrament umacnia i jakby konsekruje małżonków chrześcijańskich do obowiązków i godności ich stanu; wypełniając mocą tego sakramentu swoje zadania małżeńskie i rodzinne, przeniknięci duchem Chrystusa, który przepaja całe ich życie wiarą, nadzieją i miłością, zbliżają się małżonkowie coraz bardziej do osiagnięcia własnej doskonałości i obopólnego uświęcenia, a tym samym do wspólnego uwielbienia Boga"12. Zawarcie sakramentalnego małżeństwa implikuje specyfikę dążenia do świętości przez małżonków, która ściśle jest związana z tymże sakramentem. Jest tak przede wszystkim ze względu na podstawowy fakt, iż „nikt z małżonków nie uświęca się i nie zbawia sam, a także nie potępia się sam, zawsze bowiem pociaga za sobą współmałżonka: ku świętości albo ku potępieniu" "13. W drodze ku pełnemu udziałowi w życiu Bożym małżonkowie uczestniczą we dwoje, stąd też podstawowym skutkiem małżeństwa jest „chrześcijańska więź małżeńska, komunia dwojga typowo chrześcijańska, ponieważ przedstawia tajemnicę Wcielenia Chrystusa i tajemnicę Jego Przymierza" "14. Święty Jan Paweł II zwrócił ponadto uwagę na fakt, iż uczestniczenie małżonków w życiu Bożym posiada swoją specyfikę także z tego tytułu, iż „miłość małżeńska zawiera jakąś całkowitość, w którą wchodzą wszystkie elementy osoby - impulsy ciała i instynktu, siła uczuć i przywiązania, dążenie ducha i woli. Miłość zmierza do jedności głęboko osobowej, która nie tylko łączy w jedno ciało, ale prowadzi do tego, by było tylko jedno serce i jedna dusza"15. Papież również przypomniał, że miłość małżeńska uzdalnia małżonków do największego oddania: „małżonkowie oddając się sobie, wydają z siebie nową rzeczywistość-dziecko, żywe odbicie ich miłości, trwały znak jedności małżeń-

\footnotetext{
${ }^{11}$ Zob. J. Hadryś, Udział ochrzczonych w kapłańskim, prorockim i królewskim posłannictwie Chrystusa, „Teologia i Moralność” 10 (2015), s. 27-28.

${ }^{12}$ Sobór Watykański II, Konstytucja duszpasterska o Kościele w świecie współczesnym Gaudium et spes, 48, w: Sobór Watykański II, Konstytucje, dekrety, deklaracje, Poznań 2002, s. 526-606. Por. FC 56.

${ }^{13}$ M. Chmielewski, 101 pytań o życie duchowe, Lublin 1999, s. 137. Małżonkowie mają z każdym dniem zmierzać „ku coraz głębszej więzi pomiędzy sobą na każdym poziomie: na poziomie związku ciał, charakterów, serc, umysłów i dążeń, związku dusz, ukazując w ten sposób Kościołowi i światu nową komunię miłości jako dar łaski Chrystusowej” (FC 19).

${ }^{14} \mathrm{FC} 13$.

${ }^{15}$ Tamże. „Objawienie i właściwe urzeczywistnienie komunii kościelnej ma miejsce w rodzinie chrześcijańskiej, która również z tego powodu może i powinna nazywać się „Kościołem domowym (FC 21)". Wszyscy członkowie rodziny mają obowiązek budowania każdego dnia komunii osób. Powyższe ma się dokonywać poprzez „łaskę i miłość wobec dzieci, wobec chorych i starszych; poprzez wzajemną codzienną służbę wszystkich; poprzez dzielenie się dobrami, radościami i cierpieniami" (FC 21).
} 
skiej oraz żywą i nierozłączną syntezę ojcostwa i macierzyństwa"16. Miłość małżonków ma się stać dla dzieci widzialnym znakiem miłości Boga Ojca ${ }^{17}$.

Konkludując, należy podkreślić, iż chociaż sakrament małżeństwa jest podstawowym źródłem uświęcenia małżonków i rodziny, to owo uświęcenie opiera się przecież także na pierwotnej, chrzcielnej konsekracji, wspólnej dla wszystkich wierzących w Chrystusa, stąd także sakrament chrztu należy uznać za podstawę uświęcenia życia małżeńskiego i rodzinnego. Specyfika tegoż uświęcenia jednakże wynika z sakramentu małżeństwa, który m.in. wyznacza dążenie do pełnego udziału w życiu Bożym w ścisłym odniesieniu do osoby poślubionej, a to nakłada na małżonków wzajemną współodpowiedzialność i określa swoisty charakter ich wzajemnej miłości.

\section{MOTYWACJE OSOBISTEGO UŚWIĘCENIA MAŁŻONKÓW}

Do dążenia do pełnego udziału w życiu Bożym chrześcijańscy małżonkowie są zobowiązani przede wszystkim z racji przyjęcia sakramentów chrztu i małżeństwa. Niewątpliwie pierwszymi motywacjami dbałości o osobiste uświęcenie są zobowiązania wspólne dla wszystkich ochrzczonych, wynikające z przyjęcia sakramentu chrztu. Jak już przedstawiono w niniejszym przedłożeniu, sakrament chrztu powoduje kilka skutków. Z samego faktu otrzymania udziału w życiu Bożym wynika zobowiązanie do czuwania nad tym życiem i jego nieustannego rozwijania, gdyż życie Boże stanowi rzeczywistość dynamiczną, zakładającą współodpowiedzialność człowieka za jego rozwój, podtrzymywanie w sobie postawy nawrócenia, czyli permanentnego porzucania grzechu i oddawania siebie Bogu. Przywrócenie poprzez chrzest godności dziecka Bożego i umożliwienie uczestnictwa w życiu Osób Trójcy Przenajświętszej jest połączone z uzdolnieniem do zbawczego i uświęcającego dialogu z Bogiem i jednoczesnym wyposażeniem we wszystko, co jest do tego potrzebne, m.in. w cnoty teologalne i dary Ducha Świętego ${ }^{18}$. Ze wszczepienia w Chrystusa wynika powinność chrystoformizacji, czyli życia na podobieństwo Chrystusa oraz bezwarunkowego oddania się Jemu. To wszystko sprawia, iż przyjęcie sakramentu chrztu jest równoznaczne z otrzymaniem powołania do świętości i uzdolnienia do jego wypełnienia. Kolejny skutek sakramentu chrztu, czyli wszczepienie w Kościół, daje ochrzczonemu nie tylko prawo do korzystania ze wszelkich pomocy duchowych, które Chrystus pozostawił w swoim Kościele, ale także nakłada odpowiedzialność za wspólnotę Kościoła oraz zobowiązanie do troszczenia się o zbawienie i uświęce-

${ }^{16} \mathrm{FC} 14$

${ }^{17}$ Por. tamże.

${ }^{18}$ Por. M. Chmielewski, Chrzest, w: Leksykon duchowości katolickiej, red. M. Chmielewski, Lublin-Kraków 2002, s. 127. 
nie innych, czyli obdarza powołaniem do apostolstwa. Z udziału w potrójnym posłannictwie Chrystusa: kapłańskim, prorockim i królewskim wynikają kolejne motywacje do osobistej odpowiedzialności za rozwój życia duchowego w sobie oraz pomagania w rozwoju duchowym innym osobom ${ }^{19}$.

Przyjęcie sakramentu małżeństwa zobowiązuje małżonków do dążenia do komunii osób na wzór komunii pomiędzy osobami Trójcy Świętej, czyli osobowego zjednoczenia, obejmującego wszystkie wymiary i płaszczyzny życia człowieka, a więc stanowi kolejną motywację w osobistym dążeniu do świętości. Bez głębokiej komunii z Chrystusem trudno osiagnąć pełną jedność w małżeństwie, uwzględniającą wszystkie jego wymiary. Wzajemna miłość małżonków oraz miłość do dzieci i do wszystkich członków rodziny nie jest w stanie osiagnąć swojej pełni bez solidnych podstaw duchowych. Kolejną inspirację do dbania o rozwój życia duchowego stanowi powołanie do przekazywania życia i chrześcijańskiego wychowywania dzieci, gdyż jedynie w dobrej relacji z Chrystusem mogą małżonkowie temu sprostać. Dbanie o jedność i nierozerwalność związku wymaga oparcia się na Tym, bez którego nic dobrego nie możemy uczynić (por. J 15,5b), tak samo dawanie świadectwa wiary wobec dzieci i otoczenia jest możliwe przy zachowaniu dbałości o osobisty rozwój duchowy. Generalnie można powiedzieć, iż sam charakter chrześcijańskiego życia rodzinnego implikuje konieczność troski o uświęcenie siebie i drugiej osoby poślubionej sakramentalnie.

\section{UDZIAŁ MAŁŻONKÓW W POTRÓJNYM POSŁANNICTWIE CHRYSTUSA}

Analizując dokumenty Kościoła, poruszające problematykę udziału ochrzczonych w potrójnej misji Chrystusa ${ }^{20}$, można zauważyć, iż udział w kapłańskiej misji Chrystusa realizuje się, ogólnie rzecz ujmując, na cztery sposoby: poprzez zaangażowanie się w liturgiczny kult Kościoła, przez przeżywanie codziennego życia w ofiarowaniu siebie Bogu, przez świadectwo świętego życia oraz czynną miłość ${ }^{21}$. Powyższe stwierdzenie zakłada przyjmowanie sakramentów, modlitwę, postawę dziękczynienia, ofiarowania Bogu, realizowanie powołania do świętości ${ }^{22}$. W chrześcijańskich rodzinach kapłańskie posłannictwo ochrzczonych urzeczywistnia się w sposób specyficzny: małżonkowie troszczą się o uświęcenie wzajemne i całej rodziny poprzez wspólne, pełne uczestniczenie w Eucharystii, korzystanie z sakramentu pokuty i pojednania, modlitwę osobista, wspólną oraz z dziećmi, a także codzienne składanie duchowych darów związanych zwłaszcza

\footnotetext{
${ }^{19}$ Udział małżonków w potrójnym posłannictwie Chrystusa został szczegółowo zaprezentowany w następnej części niniejszego przedłożenia.

${ }^{20}$ Por. np. KK 9-15. Zob. J. Hadryś, Udział ochrzczonych w kapłańskim..., dz. cyt., s. 28-40. s. $60-62$.

${ }^{21}$ Por. H. Wejman, Komplementarność duchowości stanów życia w Kościele, Poznań 2002,

${ }^{22}$ Por. KK 10.
} 
z różnego rodzaju cierpieniem i trudem odpowiedzialnego wypełniania obowiązków.

Udział ochrzczonych w prorockim posłannictwie Chrystusa zobowiązuje do dawania świadectwa o Chrystusie przez życie wiarą i miłością, do posługiwania się charyzmatami, do włączania się w działania ewangelizacyjne oraz dzieła misyjne Kościoła. Owo włączanie się może dokonywać się w różny sposób, ponieważ pomaganie innym $\mathrm{w}$ dążeniu do zbawienia $\mathrm{i}$ uświęcenia realizuje się na różne sposoby: poprzez przykład życia zgodnego z wyznawaną wiara, przez konkretną pomoc świadczoną bliźnim, przez wspieranie innych słowem oraz poprzez modlitwę i ofiarowanie cierpień $\mathrm{i}$ wyrzeczeń $\mathrm{w}$ ich intencji ${ }^{23}$. Udział w prorockim urzędzie Chrystusa zobowiązuje świeckich katolików do głoszenia słowem i czynem Ewangelii oraz demaskowania wszelkich przejawów zła ${ }^{24}$. Mają się troszczyć o to, aby „,nowość i moc Ewangelii jaśniała w ich życiu codziennym, rodzinnym i społecznym, oraz cierpliwie i odważnie, pośród sprzeczności współczesnych czasów, dawać wyraz nadziei na przyszłą chwałę" ${ }^{25}$. Specyficznie swój udział w prorockiej funkcji Chrystusa realizują chrześcijańscy małżonkowie. Jest tak dlatego, że komunia miłości między Bogiem i ludźmi znajduje swój szczególny wyraz w przymierzu oblubieńczym między mężczyzną a kobietą ${ }^{26}$, stąd „małżonkowie są stałym przypomnieniem dla Kościoła tego, co dokonało się na Krzyżu; wzajemnie dla siebie i dla dzieci są świadkami zbawienia, którego uczestnikami stali się poprzez sakrament. Małżeństwo, podobnie jak każdy sakrament, jest pamiątką, uobecnieniem i proroctwem tego zbawczego dzieła"27. Już świadomość bycia chrześcijańskim małżeństwem oraz godne życie małżonków stanowi samo w sobie pełnienie przez nich prorockiej misji Chrystusa. W tym kontekście można za świętym Janem Pawłem II powtórzyć, iż w czasach nam współczesnych dawanie świadectwa nierozerwalności i wierności małżeńskiej należy do szczególnie ważnych zadań chrześcijańskich małżonków ${ }^{28}$. Małżonkowie są zatem stałym przypomnieniem dla Kościoła tego, co dokonało się na Krzyżu, dla siebie i dla dzieci są świadkami zbawienia, poprzez przyjęcie sakramentu małżeństwa otrzymują zadanie upamiętniania wielkich dzieł Bożych i świadczenia o nich wobec swych dzieci, a także życia i świadczenia o nadziei przyszłego spotkania z Chrystusem ${ }^{29}$. Warto pamię-

${ }^{23}$ Por. Franciszek, Evangelii gaudium, O głoszeniu Ewangelii $w$ dzisiejszym świecie, Rzym 2013, nr 14. Zob. W. Seremak, Ewangelizacja, w: Leksykon duchowości katolickiej, dz. cyt., s. $260-$ $-263$.

${ }^{24}$ Por. Kodeks prawa kanonicznego, Poznań 1984, 225; 227.

${ }^{25}$ Jan Paweł II, Christifideles laici, 14, Adhortacja apostolska po Synodzie Biskupów o powotaniu i misji świeckich w Kościele i w świecie dwadzieścia lat po Soborze Watykańskim II, Rzym, 30.12.1988, w: Adhortacje apostolskie Ojca Świętego Jana Pawła II, Kraków 1996. Por. KK 35.

${ }^{26}$ Por. FC 12.

${ }^{27} \mathrm{FC} 13$.

${ }^{28}$ Por. FC 20.

${ }^{29}$ Por. FC 13. 
tać, że wypełnianie przez małżonków prorockiego posłannictwa Chrystusa jest uwarunkowane poznawaniem Ewangelii i wcielaniem jej w codzienne życie: „Zależnie od tego, w jakim stopniu rodzina chrześcijańska przyjmuje Ewangelię i dojrzeje w wierze, staje się ona wspólnotą ewangelizującą" ${ }^{30}$. Wszyscy członkowie rodziny ewangelizują jak również podlegają ewangelizacji. Rodzice nie tylko dzielą się z dziećmi Ewangelią, ale mogą od nich odebrać tę Ewangelię wyrażoną głęboko życiem. Rodzina staje się głosicielką Ewangelii dla wielu rodzin oraz dla otoczenia, w którym żyje ${ }^{31}$.

Udział ochrzczonego w posłannictwie królewskim Chrystusa polega na zapanowaniu nad grzechem, czyli nad wszystkim, co sprzeciwia się godności dziecka Bożego oraz na codziennej, służebnej miłości wobec bliźnich. Zobowiązuje zatem do podtrzymywania w sobie stanu „królewskiej wolności”, odrzucania każdego przejawu grzechu w życiu osobistym i społecznym, do samozaparcia, do pokornej, cierpliwej służby bliźnim, aby w ten sposób porządkować świat skażony grzechem ${ }^{32}$. Udział w królewskiej godności Chrystusa zobowiązuje do troski nie tylko o osobistą wewnętrzną wolność, ale także o uwalnianie swoich środowisk i świata od grzechu i zła. Powyższe dotyczy również małżonków i rodziców, którzy poprzez udział w królewskiej misji Chrystusa mają szczególnie dbać o ową wolność od grzechu i zła w swoich rodzinach: pokonują oni zło mocą miłości służebnej, podejmując trud tworzenia autentycznej wspólnoty osób ${ }^{33}$. Małżonkowie wypełniają królewskie posłannictwo przez: podejmowanie tzw. ascezy małżeńskiej, w którą wpisuje się umartwienie, wyrzeczenie, cierpliwość wobec wad i ograniczeń własnych oraz członków rodziny; przez praktykowanie postawy służby wewnątrz rodziny, czyli troski o dobro, wspieranie siebie w sytuacjach trudnych, wyręczanie w obowiązkach domowych, akceptowanie siebie nawzajem i przebaczanie; przez praktykowanie postawy służby na zewnątrz, czyli zaangażowanie się w życie Kościoła lokalnego i społeczeństwa w duchu Ewangelii ${ }^{34}$. Gorliwe praktykowanie postawy służby w życiu rodzinnym i społecznym stanowi rdzeń uczestniczenia chrześcijańskich małżonków i rodziców w królewskiej misji Chrystusa ${ }^{35}$.

\footnotetext{
${ }^{30} \mathrm{FC} 52$.

31 „Apostolskie posłannictwo rodziny jest zakorzenione w chrzcie świętym, a przez łaskę sakramentu małżeństwa otrzymuje nową moc dla przekazywania wiary, dla uświęcania i przemiany współczesnego społeczeństwa wedle zamysłu Bożego" (FC 52).

${ }^{32}$ Por. KKK 943.

${ }^{33}$ Por. FC 64.

${ }^{34}$ Por. FC 21.

${ }^{35}$ Por. M. Chmielewski, 101 pytań..., dz. cyt., s. 141-142.
} 


\section{ŚRODKI, PRAKTYKI I POSTAWY POMOCNE W DAŻĖIU DO KOMUNII Z BOGIEM}

Środki, praktyki i postawy pomagające małżonkom w dążeniu do komunii z Bogiem można w ogólności podzielić na te, które wynikają z chrześcijańskiego życia duchowego oraz takie, które są związane z życiem w rodzinie. Małżonków obowiązują wszystkie praktyki religijno-duchowe, do których jest zaproszony bądź wprost zobowiązany każdy ochrzczony. Najbardziej podstawowe źródła i jednocześnie środki uświęcenia to sakramenty, modlitwa i asceza. Korzystanie z sakramentów jest konieczne, gdyż są one podstawowym źródłem uświęcenia, ponieważ w każdym z nich jest obecny Chrystus, który daje siebie ochrzczonemu zgodnie $\mathrm{z}$ łaską właściwą danemu sakramentowi. W życiu rodzinnym na czoło wysuwają się, obok sakramentów chrztu i małżeństwa, Eucharystia oraz sakrament pokuty i pojednania, które są wpisane w codzienne życie chrześcijanina i jego dążenie do pełnego udziału w życiu Bożym. Są one źródłem miłości i łaski uzdalniającej do kierowania się miłością także w sytuacjach trudnych, zakładają postawę dyspozycyjności wobec Boga i bliźnich, a także gotowość do przebaczenia i pojednania. Modlitwa jest niezbędna, aby postęp w życiu duchowym był w ogóle możliwy. Bez modlitwy nie da się prowadzić życia duchowego, jest ona pokarmem dla duszy tak jak jedzenie pokarmem dla ciała. Małżonkowie są zobowiązani nie tylko do osobistej modlitwy, ale także wspólnej oraz z dziećmi. $\mathrm{Z}$ powyższego wynika, iż ich codzienność powinna być naznaczona wieloma różnorodnymi formami modlitewnych spotkań z Bogiem. Warto również pamiętać, że potrzebują modlitwy, by być w stanie w różnych okolicznościach wybierać dobro i nim przezwyciężać zło. Asceza jest konieczna w życiu każdego ochrzczonego, aby gleba jego serca była życiodajną i przynoszącą obfite owoce miłości. Małżonkowie potrzebują jej także i z tego względu, iż przeżywają codzienność w ścisłym odniesieniu do siebie nawzajem, co samo w sobie stanowi doskonałą szkołę miłości i wezwanie do pracy nad sobą. Również ze względu na dzieci, a także na osoby starsze $\mathrm{w}$ rodzinie, bez podejmowania wysiłku pokonywania swoich słabości i przezwyciężania różnego rodzaju duchowego ubóstwa, nie będą w stanie kierować się miłością. Święty Jan Paweł II zwrócił uwagę także na fakt, iż asceza jest niezbędna dla przeżywania przez małżonków codzienności zgodnie $z$ etycznym porządkiem ${ }^{36}$. Wśród innych środków, praktyk i po-

\footnotetext{
${ }^{36}$ „Nie ulega żadnej wątpliwości, że rozumne i wolne kierowanie popędami wymaga ascezy, ażeby znaki miłości, właściwe dla życia małżeńskiego, zgodne były z etycznym porządkiem, co konieczne jest zwłaszcza dla zachowania okresowej wstrzemięźliwości. Jednakże to opanowanie, w którym przejawia się czystość małżeńska, nie tylko nie przynosi szkody miłości małżeńskiej, lecz wyposaża ją w nowe ludzkie wartości. Wymaga ono wprawdzie stałego wysiłku, ale dzięki jego dobroczynnemu wpływowi małżonkowie rozwijają w sposób pełny swoją osobowość, wzbogacając się o wartości duchowe. Opanowanie to przynosi życiu rodzinnemu obfite owoce w postaci harmonii i pokoju oraz pomaga w przezwyciężaniu innych jeszcze trudności: sprzyja trosce o współmałżonka i budzi dla niego szacunek, pomaga także małżonkom wyzbyć się egoizmu,
} 
staw duchowych zalecanych każdemu ochrzczonemu, szczególne znaczenie dla małżonków mają: praktyka pamięci na obecność Bożą, zawierzanie Bogu we wszystkim, korzystanie z kierownictwa duchowego, uczestniczenie w rekolekcjach, organizowanie osobistych bądź rodzinnych dni skupienia oraz dbałość o strefy ciszy w codziennym życiu rodzinnym.

Ze względu na życie w rodzinie, wśród szczególnie ważnych postaw bądź praktyk zalecanych chrześcijańskim małżonkom należy wymienić jeszcze umiejętność akceptacji i przebaczenia, cierpliwość, dyspozycyjność, służebność i pokorę $^{37}$. Akceptacja jest pierwszym warunkiem zdolności do prawdziwej miłości i jednocześnie jej wyrazem, a należy ją rozumieć jako akceptację siebie oraz każdego z członków rodziny wraz ze słabościami i ludzkimi ograniczeniami. Akceptacja siebie jest niezbędna, aby móc zaakceptować bliźniego, a dopiero po zaakceptowaniu bliźniego takim, jakim jest, można go podjąć z miłością i owocnie jemu pomóc. Postawa przebaczenia jest konieczna z tego względu, iż w życiu wspólnym, jakim jest niewątpliwie życie w rodzinie, nieuniknione są sytuacje i zdarzenia, które mogą wywoływać frustrację, irytację czy negatywne uczucia, stąd jest konieczna umiejętność radzenia sobie z uczuciami i emocjami w konstruktywny sposób ${ }^{38}$. Z tych samych względów potrzebna jest cierpliwość, zwłaszcza wobec wad i słabości własnych oraz członków rodziny. Wzrastanie w miłości w życiu rodzinnym oznacza też postawę dyspozycyjności, czyli gotowości pomocy oraz służby, umiejętność wychodzenia naprzeciw pragnieniom i oczekiwaniom najbliższych, nawet za cenę zaparcia się siebie i przezwyciężenia swojego egoizmu. Przyjęcie takiej postawy bardzo pomaga w rozwoju duchowym, ciagle przypomina istotę prawdziwej miłości, którą stanowi troska o dobro miłowanej osoby, z gotowością do poświęcenia siebie dla jej dobra ${ }^{39}$. Pokora w życiu rodzinnym pozwala $\mathrm{z}$ realizmem podejmować codzienność i w prawdzie oceniać siebie oraz swoich bliskich, co jest niezbędne, aby uniknąć iluzji dotyczącej zarówno życia rodzinnego, jak i duchowego.

sprzeciwiającego się prawdziwej miłości oraz wzmacnia w nich poczucie odpowiedzialności. A wreszcie dzięki opanowaniu siebie rodzice uzyskują głębszy i skuteczniejszy wpływ wychowawczy na potomstwo" (FC 33). Por. Paweł VI, Humanae vitae, Encyklika o zasadach moralnych w dziedzinie przekazywania życia ludzkiego, Rzym 25.07.1968, Kraków 1968, 21.

${ }^{37}$ Do warunków koniecznych w życiu małżeńskim należy zaliczyć „stałość i cierpliwość, pokorę i moc ducha, dziecięce zaufanie Bogu i Jego łasce" (FC 33).

38 „Komunia rodzinna może być zachowana i doskonalona jedynie w wielkim duchu ofiary. Wymaga bowiem szlachetnej gotowości każdego i wszystkich do zrozumienia, tolerancji, przebaczenia i pojednania" (FC 21).

${ }^{39}$, „Każdy akt prawdziwej miłości wobec człowieka potwierdza i doskonali duchową płodność rodziny, będąc aktem posłuszeństwa wobec głębokiego, wewnętrznego dynamizmu miłości, rozumianej jako oddawanie siebie innym" (FC 41). 


\section{PODSUMOWANIE}

W świetle przeprowadzonych w niniejszym przedłożeniu badań nad znaczeniem życia w rodzinie chrześcijańskich małżonków, dążących do pełnego udziału w życiu Bożym, można postawić następujące tezy:

1. Istnieją trzy istotne elementy, składające się na pełnię chrześcijańskiego życia: głęboka, osobista więź z Chrystusem, troszczenie się o poznanie i wypełnienie woli Bożej oraz umiłowanie Kościoła. W każdym z określeń pełni życia chrześcijańskiego te elementy występują, chociaż są różnie akcentowane. Więź z Chrystusem podkreślają szczególnie określenia ujmujące pełnię życia duchowego jako zjednoczenie bądź komunię z Bogiem, z kolei wymiar moralny te, które akcentują doskonałość bądź pełnienie woli Bożej. Wydaje się, iż mówiąc o świętości lub o naśladowaniu Chrystusa, najlepiej łączy się wszystkie wymiary składające się na pełnię życia chrześcijańskiego. Ponieważ miarą świętości jest miłość, dlatego radykalne życie według przykazania miłości Boga i bliźniego można uznać za najistotniejszy element pełnego udziału w życiu Bożym.

2. Sakrament małżeństwa jest podstawowym źródłem uświęcenia małżonków i rodziny, jednakże ze względu na fakt, iż uświęcenie opiera się na pierwotnej, chrzcielnej konsekracji, także sakrament chrztu należy uznać za podstawę uświęcenia małżonków. Specyfika uświęcenia małżonków wynika z życia w rodzinie, a szczególnie z przyjętego sakramentu małżeństwa, który wyznacza ich dążenie do pełnego udziału w życiu Bożym w ścisłym odniesieniu do osoby poślubionej. Powyższe stwierdzenie określa swoisty charakter wzajemnej miłości oraz zakłada współodpowiedzialność za nią.

3. Małżonkowie są zobowiązani do dążenia do pełnego udziału w życiu Bożym przede wszystkim z racji przyjęcia sakramentów chrztu i małżeństwa. Każdy ochrzczony jest wezwany do życia na podobieństwo Chrystusa oraz bezwarunkowego oddania się Jemu. Przyjęcie sakramentu chrztu jest równoznaczne $\mathrm{z}$ otrzymaniem powołania do świętości i uzdolnienia do jego wypełnienia. $Z$ kolei przyjęcie sakramentu małżeństwa zobowiązuje małżonków do dążenia do komunii osób na wzór komunii pomiędzy osobami Trójcy Świętej, co nie jest możliwe bez osobistej i głębokiej komunii z Chrystusem. Inspirację do dbania o rozwój życia duchowego stanowi także powołanie małżonków do przekazywania życia i chrześcijańskiego wychowywania dzieci, a także dbanie o jedność i nierozerwalność związku oraz dawanie świadectwa wiary wobec dzieci i otoczenia. $Z$ powyższego spostrzeżenia wynika, iż sam charakter chrześcijańskiego życia duchowego oraz charakter życia rodzinnego implikują konieczność troski o uświęcenie siebie i drugiej osoby poślubionej sakramentalnie. 
4. Udział małżonków w potrójnym posłannictwie Chrystusa: kapłańskim, prorockim i królewskim stanowi kolejne motywacje do dbania o rozwój życia duchowego w sobie, jak również pomagania w rozwoju duchowym bliźnim. Wynika on z przyjętego sakramentu chrztu, ale jego specyfikę określa życie w rodzinie. Małżonkowie troszczą się o uświęcenie wzajemne i całej rodziny poprzez uczestniczenie w Eucharystii, regularne korzystanie z sakramentu pokuty i pojednania, modlitwę, codzienne składanie Bogu duchowych darów. Dla Kościoła są stałym przypomnieniem tego, co dokonało się na Krzyżu, dla siebie i dla dzieci są świadkami zbawienia, mają zadanie upamiętniania wielkich dzieł Bożych i świadczenia o nich wobec swych dzieci. Mają szczególnie dbać o wolność od grzechu i zła, w swoich rodzinach pokonując zło mocą miłości służebnej. Mają podejmować tzw. ascezę małżeńską, w którą wpisuje się m.in. umartwienie oraz cierpliwość wobec wad i ograniczeń własnych oraz członków rodziny, mają praktykować postawę służby wewnątrz rodziny i na zewnątrz.

5. Małżonkowie są zobowiązani do podejmowania praktyk religijno-duchowych, do których jest zobowiązany każdy ochrzczony. Najbardziej podstawowe to sakramenty, modlitwa i asceza, ale także szczególną wartość w drodze ku pełni życia w Bogu w życiu małżonków mają: praktyka pamięci na obecność Bożą, zawierzanie Bogu we wszystkim, korzystanie z kierownictwa duchowego, uczestniczenie w rekolekcjach i dniach skupienia oraz dbałość o ciszę w codziennym życiu rodzinnym. Ze względu na życie w rodzinie, wśród szczególnie ważnych postaw bądź praktyk należy wymienić jeszcze umiejętność akceptacji i przebaczenia, cierpliwość, dyspozycyjność, służebność i pokorę.

Święty Jan Paweł II nie tylko uważał małżeństwo za drogę prowadzącą do świętości, ale jego pragnieniem było ukazywanie konkretnych wzorów kroczenia tą drogą: Należy popierać uznanie heroiczności cnót zwłaszcza światobliwych wiernych świeckich, którzy realizowali swe powołanie chrześcijańskie $w$ matżeństwie. Żywiqc przeświadczenie, że w rzeczywistości nie brak owoców świętości również w tym stanie, czujemy potrzebę znalezienia odpowiednich sposobów, ażeby świętość ta byta przez Kościót stwierdzana i stawiana za wzór dla innych chrześcijańskich matżonków $w^{40}$.

\footnotetext{
${ }^{40}$ Jan Paweł II, Tertio Millennio Adveniente, 37, List apostolski w związku z przygotowaniem Jubileuszu Roku 2000, w: Wybór Listów Ojca Świętego Jana Pawła II, t. I, Kraków 1997, s. 167-205.
} 


\section{SUMMARY}

The article presents the results of the analysis of Christian family life from the point of view of its role in the spouses' striving for full participation in the life of God. First, the essential elements of participation in the life of God were pointed out, then the base and the specificity of the sanctification of the spouses in the family, also the motivations of personal sanctification and their participation in the threefold mission of Christ, and at the end the measures, practices, and attitudes helpful in the pursuit of full life of God through the life in the family were presented. The results of the conducted analysis are included at the end. It was found that there are three essential elements of the fullness of Christian life: a deep, personal relationship with Christ, caring for knowledge and fulfillment of God's will, and love of the Church. It has been shown that the spouses are obliged to strive for full participation in the divine life, mainly due to the obtained sacraments of baptism and marriage, and the specifics of their sanctification results from the life in the family, especially from the sacrament of marriage which determines their desire to participate fully in the life of God in the strict reference to the spouse. It was found that the very nature of the Christian spiritual life and the nature of family life imply the need to care for the sanctification of oneself and the spouse married sacramentally. The obligations arising from participation in the threefold mission of Christ: priestly, prophetic and kingly and their specific character in the family life have been highlighted. It has been shown that the spouses are called to undertake the religious and spiritual practices which are required by every baptized person, and because of the family life, among the particularly important attitudes or practices, ability of acceptance and forgiveness, patience, availability, servitude and humility have been mentioned.

\section{Keywords}

God, Christ, baptism, marriage, family, state of life, fullness of life, holiness

\section{BIBLIOGRAFIA}

\section{Pismo Święte}

Pismo Święte Starego i Nowego Testamentu, Biblia Tysiąclecia, Poznań-Warszawa 1980.

\section{Dokumenty Kościoła i nauczanie papieskie}

Franciszek, Evangelii gaudium. O głoszeniu Ewangelii w dzisiejszym świecie, Rzym 2013.

Jan Paweł II, Christifideles laici, Adhortacja apostolska po Synodzie Biskupów o powołaniu i misji świeckich $w$ Kościele $i$ w świecie dwadzieścia lat po Soborze Watykańskim II, Rzym, 30.12.1988, w: Adhortacje apostolskie Ojca Świętego Jana Pawła II, Kraków 1996, s. 345-480.

Jan Paweł II, Familiaris consortio, Adhortacja apostolska do biskupów, kapłanów i wiernych całego Kościoła Katolickiego o zadaniach rodziny chrześcijańskiej w świecie współczesnym, Rzym 22.11.1981, w: Adhortacje apostolskie Ojca Świętego Jana Pawła II, Kraków 1996, s. 87-208.

Jan Paweł II, Tertio Millennio Adveniente, 37, List apostolski w związku z przygotowaniem Jubileuszu Roku 2000, w: Wybór Listów Ojca Świętego Jana Pawła II, t. 1, Kraków 1997, s. 167-205. 
Paweł VI, Humanae vitae, 21, Encyklika o zasadach moralnych $w$ dziedzinie przekazywania życia ludzkiego, Rzym 25.07.1968, Kraków 1968.

Katechizm Kościoła katolickiego, Poznań 1999.

Kodeks prawa kanonicznego, Poznań 1984.

Sobór Watykański II, Konstytucja dogmatyczna o Kościele Lumen gentium, w: Sobór Watykański II, Konstytucje, dekrety, deklaracje, Poznań 2002, s. s. 104-166.

Sobór Watykański II, Konstytucja duszpasterska o Kościele w świecie współczesnym Gaudium et spes, w: Sobór Watykański II, Konstytucje, dekrety, deklaracje, Poznań 2002, s. 526-606.

\section{Literatura przedmiotu i pomocnicza}

Chmielewski M., Chrzest, w: Leksykon duchowości katolickiej, red. M. Chmielewski, Lublin-Kraków 2002, s. 126-130.

Chmielewski M., 101 pytań o życie duchowe, Lublin 1999.

Hadryś J., Matżeństwo droga do komunii z Bogiem w świetle „Familiaris consortio” Jana Pawła II, „Teologia i Moralność” 9 (2011), s. 25-39.

Hadryś J., Różne ujęcia petni życia chrześcijańskiego, w: Zawsze z Tobq. Księa pamiatkowa ofiarowana biskupowi Zdzisławowi Fortuniakowi na pięćdziesięciolecie kapłaństwa, Poznań, s. 243-247.

Hadryś J., Udział ochrzczonych $w$ kapłańskim, prorockim i królewskim posłannictwie Chrystusa, „Teologia i Moralność” 10 (2015), s. 27-43.

Hildebrand D. von, Transformation in Christ, San Francisco 2001.

Gogola J., Teologia komunii z Bogiem, Kraków 2003.

Marchetti A., Zarys teologii życia duchowego, cz. I, Kraków 1996.

Seremak W., Ewangelizacja, w: Leksykon duchowości katolickiej, red. M. Chmielewski, Lublin-Kraków 2002, s. 260-263.

Wejman H., Komplementarność duchowości stanów życia w Kościele, Poznań 2002.

Jacek Hadryś - kapłan archidiecezji poznańskiej, dr hab. teologii, profesor UAM, wykładowca teologii duchowości, kierownik Zakładu Teologii Moralnej, Duchowości i Katolickiej Nauki Społecznej na Wydziale Teologicznym Uniwersytetu Adama Mickiewicza w Poznaniu, dyrektor Szkoły Katechistów Archidiecezji Poznańskiej, cenzor ksiąg religijnych. 